\title{
Bronchopleural Fistula associated Tension Pneumothorax in SARS- COVID 19: A case report
}

\author{
Milan Regmi ${ }^{1}$, Moon Shrestha ${ }^{1}$, Nibesh Pathak ${ }^{2}$, Niraj Sharma ${ }^{1}$, and Pankaj Pant ${ }^{2}$ \\ ${ }^{1}$ Tribhuvan University Teaching Hospital \\ ${ }^{2}$ Tribhuvan University Institute of Medicine
}

November 28, 2021

\begin{abstract}
COVID-19 can cause pneumothorax but pneumothorax in COVID-19 patient associated with bronchopleural fistula is very rarely reported. We present this unusual case of Tension Pneumothorax in COVID -19 Patient associated with Bronchopleural Fistula.
\end{abstract}

\section{Hosted file}

BPF aw Pneumo.doc available at https://authorea.com/users/447150/articles/547126bronchopleural-fistula-associated-tension-pneumothorax-in-sars-covid-19-a-case-report 